\title{
PENGARUH APLIKASI SILIKA DAN BORON TERHADAP PERTUMBUHAN DAN PRODUKSI TANAMAN PADI (Oryza sativa L.)
}

\author{
Rifky Artha Prawira, Agustiansyah, Yohanes Ginting,M \& Yayuk Nurmiaty \\ Jurusan Agroteknologi, Fakultas Pertanian Universitas Lampung \\ Jl. Prof. Soemantri Brodjonegoro, No 1, Bandarlampung 35145 \\ E-mail: rifkyarthaprawira@yahoo.co.id
}

\begin{abstract}
ABSTRAK
Produktivitas padi di Indonesia masih rendah dibandingkan dengan potensi produksi padi yang ada sehingga belum dapat memenuhi kebutuhan konsumen yang terus meningkat. Salah satu cara untuk meningkatkan produksi padi dapat dilakukan dengan penerapan teknologi budidaya yang optimal terutama dalam penggunaan benih bermutu dan pemupukan. Silika dapat menjadikan daun tanaman padi lebih tegak sehingga penangkapan cahaya matahari dan proses fotosintesis lebih efisien. Boron digunakan untuk pembelahan sel, pembentukan buah, dan mengatur metabolisme karbohidrat. Penelitian ini bertujuan untuk: (1) mengetahui pengaruh pemberian silika terhadap pertumbuhan dan produksi tanaman padi, (2) mengetahui pengaruh pemberian boron terhadap pertumbuhan dan produksi tanaman padi, dan (3) mengetahui pengaruh interaksi silika dan boron terhadap pertumbuhan dan produksi tanaman padi. Penelitian ini dilaksanakan di rumah kaca Laboratorium Lapang Terpadu dan Laboratorium Benih dan Pemuliaan Tanaman Fakultas Pertanian Universitas Lampung pada bulan Januari sampai Mei 2013. Rancangan perlakuan disusun secara faktorial (5x3). Faktor pertama adalah dosis silika yang terdiri dari 5 taraf, yaitu 0 $\mathrm{mg} \mathrm{kg}^{-1}\left(\mathrm{~S}_{0}\right), 100 \mathrm{mg} \mathrm{kg}^{-1}\left(\mathrm{~S}_{1}\right), 200 \mathrm{mg} \mathrm{kg}^{-1}\left(\mathrm{~S}_{2}\right), 300 \mathrm{mg} \mathrm{kg}^{-1}\left(\mathrm{~S}_{3}\right)$, dan $400 \mathrm{mg} \mathrm{kg}^{-1}\left(\mathrm{~S}_{4}\right)$. Faktor kedua adalah dosis boron yang terdiri dari 3 taraf, yaitu $0 \mathrm{mg} \mathrm{l}^{-1}\left(\mathrm{~B}_{0}\right), 5 \mathrm{mg} \mathrm{l}^{-1}\left(\mathrm{~B}_{1}\right)$, dan $10 \mathrm{mg} \mathrm{l}^{-1}\left(\mathrm{~B}_{2}\right)$. Hasil penelitian menunjukkan bahwa pemberian silika secara tunggal berpengaruh terhadap pertumbuhan dan produksi tanaman padi pada variabel tinggi tanaman pada fase vegetatif, persentase gabah isi dan jumlah gabah hampa. Sedangkan pemberian boron secara tunggal berpengaruh terhadap produksi tanaman padi pada variabel persentase gabah isi dan jumlah gabah hampa. Interaksi silika dan boron terdapat pada perlakuan silika $400 \mathrm{mg} \mathrm{kg}^{-1}$ dan boron $10 \mathrm{mg} \mathrm{l}^{-1}$ yang memberikan pengaruh terhadap jumlah anakan, jumlah malai, jumlah gabah isi, persentase gabah isi, bobot gabah isi, dan jumlah gabah hampa.
\end{abstract}

Kata kunci: boron, padi, silika.

\section{PENDAHULUAN}

Padi (Oryza sativa L.) merupakan bahan makanan pokok sebagian besar rakyat Indonesia. Prospek pengembangan untuk mencukupi bahan pangan akan terus meningkat sejalan dengan pertambahan jumlah penduduk dan peningkatan konsumsi per kapita sehingga permintaan akan beras juga akan meningkat. Peningkatan luas panen padi tidak diikuti dengan peningkatan produksi padi sehingga permintaan akan padi masih belum dapat terpenuhi. Rendahnya produksi padi yang dihadapi sampai saat ini salah satunya ketersediaan benih bermutu yang masih rendah. Benih bermutu adalah benih murni dari suatu varietas, berukuran penuh dan seragam, serta daya kecambah di atas $80 \%$ (International Rice Research Institute, 2007).

Upaya peningkatan produksi dapat dilakukan dengan meningkatkan efisiensi penggunaan pupuk, karena salah satu faktor yang membatasi produksi tanaman adalah unsur hara. Menurut Salam (2012), tanaman memerlukan seperangkat unsur hara esensial.
Berdasarkan jumlah kebutuhan hara yang dibutuhkan tanaman, unsur hara esensial dibagi menjadi dua kelompok besar, yaitu: unsur hara makro dan unsur hara mikro. Kekurangan unsur hara tersebut akan menyebabkan terganggunya metabolisme tanaman sehingga tahapan pertumbuhan dan perkembangan tanaman terganggu dan menunjukkan gejala defisiensi unsur hara.

Silika ( $\mathrm{Si}$ ) merupakan unsur kedua terbanyak dalam kerak bumi (Sommer et al., 2006). Tanaman serealia dan rumput-rumputan mengandung $\mathrm{Si}$ sebesar 0,2-2,0\%, sedangkan tanaman dikotil mengandung sepersepuluhnya. Silika berfungsi memperkuat dinding jaringan epidermis dan jaringan pembuluh, mengurangi kekurangan air, dan menghambat infeksi jamur (Makarim, Suhartatik, dan Kartohardjono, 2007).

Selain silika, boron merupakan salah satu dari 16 unsur hara yang penting untuk pertumbuhan tanaman. Boron digunakan untuk pembelahan sel, pembentukan buah, perkembangan benih, translokasi gula dan pati, sintesis asam amino dan protein, dan mengatur 
metabolisme karbohidrat. Ketersediaan boron di dalam tanah sebesar 0,10-5,0 ppm sedangkan kebutuhan normal boron untuk tanaman monokotil sebesar 6,0-18,0 ppm dan tanaman dikotil sebesar 20,0-60,0 ppm (Heckman, 2000).

Penelitian ini bertujuan untuk: (1) mengetahui pengaruh pemberian silika terhadap pertumbuhan dan produksi tanaman padi, (2) mengetahui pengaruh pemberian boron terhadap pertumbuhan dan produksi tanaman padi, dan (3) mengetahui pengaruh interaksi silika dan boron terhadap pertumbuhan dan produksi tanaman padi.

\section{BAHAN DAN METODE}

Penelitian dilaksanakan di Rumah Kaca Laboratorium Lapang Terpadu dan Laboratorium Benih dan Pemuliaan Tanaman Lampung Fakultas Pertanian Universitas Lampung. Penelitiaan dilakukan dari bulan Januari-Mei 2013. Rancangan perlakuan disusun secara faktorial $(5 \times 3)$. Faktor pertama adalah dosis silika yang terdiri dari 5 taraf, yaitu $0 \mathrm{mg} \mathrm{kg}^{-1}$ tanah setara dengan $0 \mathrm{~kg} \mathrm{ha}^{-1}\left(\mathrm{~S}_{0}\right), 100 \mathrm{mg} \mathrm{kg}^{-1}$ tanah setara dengan $100 \mathrm{~kg}$ $\mathrm{ha}^{-1}$ (S1), $200 \mathrm{mg} \mathrm{kg}^{-1}$ tanah setara dengan $200 \mathrm{~kg} \mathrm{ha}^{-1}$ (S2), $300 \mathrm{mg} \mathrm{kg}^{-1}$ tanah setara dengan $300 \mathrm{~kg} \mathrm{ha}^{-1}$ (S3), dan $400 \mathrm{mg} \mathrm{kg}^{-1}$ tanah setara dengan $400 \mathrm{~kg} \mathrm{ha}^{-1}$ (S4). Faktor kedua adalah dosis boron yang terdiri dari 3 taraf, yaitu $0 \mathrm{mg} \mathrm{l}^{-1}$ air (B0), $5 \mathrm{mg} \mathrm{l}^{-1}$ air (B1), dan $10 \mathrm{mg} \mathrm{l}^{-1}$ air (B2). Perlakuan diterapkan pada petak percobaan dalam Rancangan Teracak Sempurna (RTS) dengan 4 kali ulangan. Homogenitas ragam antarperlakuan diuji dengan uji Bartlett dan aditivitas data dengan uji Tukey, analisis data dilakukan dengan analisis ragam yang dilanjutkan dengan uji BNJ pada taraf $\alpha 5 \%$.

Pelaksanaan penelitian meliputi persiapan media tanam, persemaian, penanaman, penyulaman, perlakuan pemupukan, pemeliharaan dan panen. Tanah yang digunakan sebagai media tanam digemburkan kemudian dimasukkan ke dalam masing-masing ember sebanyak $\pm 10 \mathrm{~kg}$. Setelah itu, media digenangi dan dilakukan pelumpuran selama dua minggu. Persemaian dilakukan dengan cara menabur benih ke dalam ember yang telah terisi media tanam macak-macak. Setelah semaian berumur 12 hari, bibit tersebut dipindahkan ke masingmasing ember perlakuan sebanyak satu bibit per ember. Penyulaman dilakukan pada saat satu minggu setelah tanam. Penyulaman dilakukan bila bibit dalam satu ember tidak tumbuh. Perlakuan silika menggunakan natrium silikat dengan $\mathrm{Na}_{2} \mathrm{SiO}_{3}$ sebagai sumbernya yang dilakukan dua minggu sebelum tanam. Kebutuhan silika $100 \mathrm{mg} \mathrm{kg}^{-1}$ tanah adalah $0,43 \mathrm{~g}, 200 \mathrm{mg} \mathrm{kg}^{-1}$ tanah adalah $0,87 \mathrm{~g}, 300 \mathrm{mg} \mathrm{kg}^{-1}$ tanah adalah $1,30 \mathrm{~g}$, dan $400 \mathrm{mg} \mathrm{kg}$ ${ }^{1}$ tanah adalah $1,74 \mathrm{~g}$. Perlakuan boron $\left(\mathrm{H}_{3} \mathrm{BO}_{3}\right)$ dilakukan dengan cara disemprotkan ke tanaman padi pada umur empat minggu setelah tanam kemudian dua minggu sekali sampai menjelang pengisian bulir. Kebutuhan boron $5 \mathrm{mg} \mathrm{l}^{-1}$ adalah $0,03 \mathrm{~g}_{\text {dan }} 10 \mathrm{mg} \mathrm{l}^{-1}$ adalah $0,06 \mathrm{~g}$. Pemeliharaan tanaman dilakukan dengan penggenangan media tanam dan pengendalian hama dan penyakit tanaman. Pemanenan dilakukan pada saat $90 \%$ atau lebih kondisi tanaman padi telah menguning atau masak panen.

\section{HASIL DAN PEMBAHASAN}

Tidak terdapat interaksi antara silika dan boron pada tinggi tanaman padi. Hasil penelitian menunjukkan bahwa pemberian silika secara tunggal meningkatkan tinggi tanaman padi. Respons tanaman terhadap pemberian silika secara tunggal mendapatkan tinggi tanaman maksimal dengan pemberian silika $200 \mathrm{mg}$ $\mathrm{kg}^{-1}$ yaitu $92,18 \mathrm{~cm}$ dan tinggi tanaman minimum pada pemberian silika $300 \mathrm{mg} \mathrm{kg}^{-1}$ yaitu 82,35 $\mathrm{cm}$ (Tabel 1). Menurut Ma dan Takahashi (2002), pemberian silika

Tabel 1. Pengaruh pemberian silika terhadap tinggi tanaman padi umur 1-6 minggu setelah tanaman (MST).

\begin{tabular}{lcccccc}
\hline \multirow{2}{*}{ Perlakuan } & \multicolumn{5}{c}{ Tinggi tanaman $(\mathrm{cm})$} \\
\cline { 2 - 7 } & $1 \mathrm{MST}$ & $2 \mathrm{MST}$ & $3 \mathrm{MST}$ & $4 \mathrm{MST}$ & $5 \mathrm{MST}$ & $6 \mathrm{MST}$ \\
\hline $0 \mathrm{mg} \mathrm{kg}^{-1}$ & $32,26 \mathrm{a}$ & $45,10 \mathrm{a}$ & $61,08 \mathrm{a}$ & $76,74 \mathrm{a}$ & $88,31 \mathrm{a}$ & $90,81 \mathrm{a}$ \\
$100 \mathrm{mg} \mathrm{kg}^{-1}$ & $32,08 \mathrm{a}$ & $45,63 \mathrm{a}$ & $61,33 \mathrm{a}$ & $76,66 \mathrm{a}$ & $87,83 \mathrm{a}$ & $90,58 \mathrm{a}$ \\
$200 \mathrm{mg} \mathrm{kg}^{-1}$ & $32,44 \mathrm{a}$ & $44,48 \mathrm{a}$ & $59,38 \mathrm{a}$ & $74,68 \mathrm{a}$ & $88,53 \mathrm{a}$ & $92,18 \mathrm{a}$ \\
$300 \mathrm{mg} \mathrm{kg}^{-1}$ & $28,73 \mathrm{a}$ & $36,38 \mathrm{~b}$ & $48,98 \mathrm{~b}$ & $63,63 \mathrm{~b}$ & $73,76 \mathrm{~b}$ & $82,35 \mathrm{a}$ \\
$400 \mathrm{mg} \mathrm{kg}^{-1}$ & $31,71 \mathrm{a}$ & $44,63 \mathrm{a}$ & $59,66 \mathrm{a}$ & $74,95 \mathrm{a}$ & $85,29 \mathrm{a}$ & $87,48 \mathrm{a}$ \\
\hline BNJ 5\% & 5,93 & 7,82 & 10,27 & 10,78 & 11,45 & 12,77 \\
\hline
\end{tabular}

Keterangan: Angka pada tiap kolom yang diikuti dengan huruf yang sama tidak berbeda menurut uji BNJ pada $\alpha$ $=5 \%$. 
pada fase generatif padi lebih efektif dalam meningkatkan pertumbuhan tanaman dibandingkan dengan fase vegetatif. Aziz, Gill, and Rahmatullah (2002) dan Mauad et al. (2003) melaporkan dalam penelitiannya bahwa penerapan silika pada tanaman padi dapat meningkatkan laju pertumbuhan dan tinggi tanaman. Respons tanaman terhadap pemberian boron secara tunggal mendapatkan tinggi tanaman maksimal tanpa pemberian boron yaitu $90,03 \mathrm{~cm}$ (Tabel 2). Hasil penelitian ini sesuai dengan hasil penelitian Ahmad et al. (2012) namun bertentangan dengan hasil penelitian Khan et al. (2011) dan Sarki et al. (2013) yang melaporkan bahwa aplikasi boron pada tanaman padi dapat meningkatkan tinggi tanaman dan meningkatkan laju pertumbuhan tanaman.

Terdapat interaksi silika dan boron terhadap jumlah anakan dan jumlah malai. Berdasarkan deskripsi tanaman padi varietas ciherang, jumlah anakan produktif tanaman padi mencapai $14-17$ batang. Tabel 3 menunjukkan bahwa tanaman yang diberi silika $400 \mathrm{mg}$ $\mathrm{kg}^{-1}$ dan boron $10 \mathrm{mg} \mathrm{l}^{-1}$ memiliki jumlah anakan terbanyak yaitu 18,84 batang. Semakin banyak jumlah anakan maka semakin banyak jumlah malai karena setiap anakan menghasilkan satu malai. Jumlah malai mencapai optimum dan memiliki jumlah malai terbanyak pada perlakuan yang diberi silika $400 \mathrm{mg} \mathrm{kg}^{-1}$ dan boron $10 \mathrm{mg} \mathrm{l}^{-1}$ yaitu 17,08 malai (Tabel 6). Yasari et al. (2012) dan Kim et al. (2012) yang masing-masing melaporkan dalam penelitiannya bahwa pemberian silika dapat meningkatkan jumlah anakan dan jumlah malai tanaman padi. Hasil penelitian ini juga sesuai dengan hasil penelitian Khan et al. (2011) yang melaporkan bahwa pemberian boron pada tanaman padi dapat meningkatkan jumlah anakan dan jumlah malai tanaman padi. Menurut Sarki et al. (2013), peningkatan jumlah malai pada tanaman padi dipengaruhi oleh boron dalam reproduksi tanaman dan perkecambahan serbuk sari sehingga boron mendorong pertumbuhan tabung polen.

Pengaruh perlakuan menunjukkan bahwa pemberian silika dan boron secara tunggal tidak berpengaruh terhadap bobot basah tanaman dan bobot berangkasan kering. Perlakuan silika $200 \mathrm{mg} \mathrm{kg}^{-1}$ memiliki bobot basah tanaman tertinggi yaitu $179,49 \mathrm{~g}$ (Tabel 4) dan bobot berangkasan kering tertinggi yaitu $61,93 \mathrm{~g}$ (Tabel 5). Perlakuan tanpa diberi boron memiliki bobot basah tanaman tertinggi yaitu 179,35 g (Tabel 4) dan bobot berangkasan kering tertinggi yaitu 59,61 g (Tabel 5). Hasil penelitian ini bertentangan dengan hasil

Tabel 2. Pengaruh pemberian boron terhadap tinggi tanaman padi umur 1-6 minggu setelah tanaman (MST).

\begin{tabular}{lcccccc}
\hline \multirow{2}{*}{ Perlakuan } & \multicolumn{7}{c}{ Tinggi tana man $(\mathrm{cm})$} \\
\cline { 2 - 7 } & $1 \mathrm{MST}$ & 2 MST & 3 MST & $4 \mathrm{MST}$ & $5 \mathrm{MST}$ & $6 \mathrm{MST}$ \\
\hline $\mathrm{n} \mathrm{mg} \mathrm{l}^{-1}$ & $31,49 \mathrm{a}$ & $43,64 \mathrm{a}$ & $59,50 \mathrm{a}$ & $74,63 \mathrm{a}$ & $85,80 \mathrm{a}$ & $90,03 \mathrm{a}$ \\
$5 \mathrm{~m} \mathrm{l}^{-1}$ & $31,14 \mathrm{a}$ & $43,71 \mathrm{a}$ & $57,68 \mathrm{a}$ & $72,80 \mathrm{a}$ & $84,83 \mathrm{a}$ & $87,48 \mathrm{a}$ \\
$10 \mathrm{mg} \mathrm{l}^{-1}$ & $31,71 \mathrm{a}$ & $43,09 \mathrm{a}$ & $57,07 \mathrm{a}$ & $72,57 \mathrm{a}$ & $83,60 \mathrm{a}$ & $88,53 \mathrm{a}$ \\
\hline BNJ 5\% & 5,93 & 7,82 & 10,27 & 10,78 & 11,45 & 12,77 \\
\hline
\end{tabular}

Keterangan : Angka yang diikuti dengan huruf yang sama tidak berbeda menurut uji BNJ pada $\alpha=5 \%$.

Tabel 3. Pengaruh interaksi silika dan boron terhadap jumlah anakan tanaman padi (Data detransformasi akar).

\begin{tabular}{cccc}
\hline \multirow{2}{*}{ Perlakuan } & \multicolumn{3}{c}{ Boron } \\
\cline { 2 - 4 } & $0 \mathrm{mg} \mathrm{l}^{-1}$ & $5 \mathrm{mg} \mathrm{l}^{-1}$ & $10 \mathrm{mg} \mathrm{l}^{-1}$ \\
\hline Silika & \multicolumn{3}{c}{ Jumlah anakan (batang) } \\
\hline $0 \mathrm{mg} \mathrm{kg}^{-1}$ & $14,94 \mathrm{~A} \mathrm{(a)}$ & $12,92 \mathrm{~A} \mathrm{(a)}$ & $13,71 \mathrm{~A} \mathrm{(a)}$ \\
$100 \mathrm{mg} \mathrm{kg}^{-1}$ & $14,27 \mathrm{~A} \mathrm{(a)}$ & $13,16 \mathrm{~A} \mathrm{(a)}$ & $10,38 \mathrm{~A} \mathrm{(a)}$ \\
$200 \mathrm{mg} \mathrm{kg}^{-1}$ & $14,27 \mathrm{~A} \mathrm{(a)}$ & $13,30 \mathrm{~A} \mathrm{(a)}$ & $14,44 \mathrm{~A} \mathrm{(a)}$ \\
$300 \mathrm{mg} \mathrm{kg}^{-1}$ & $11,42 \mathrm{~A} \mathrm{(a)}$ & $16,46 \mathrm{~A} \mathrm{(a)}$ & $13,51 \mathrm{~A} \mathrm{(a)}$ \\
$400 \mathrm{mg} \mathrm{kg}^{-1}$ & $14,48 \mathrm{~A} \mathrm{(a)}$ & $9,69 \mathrm{~A}(\mathrm{~b})$ & $18,84 \mathrm{~A} \mathrm{(a)}$ \\
\hline
\end{tabular}

BNJ $5 \%$ 4,34

Keterangan : Angka pada tiap kolom yang diikuti dengan huruf yang sama (besar = horizontal, kecil = vertikal) tidak berbeda nyata menurut uji BNJ pada $\alpha=5 \%$. 
Tabel 4. Pengaruh pemberian silika terhadap bobot basah tanaman dan bobot kering tanaman padi (Data detransformasi antilog).

\begin{tabular}{ccc}
\hline Perlakuan & Bobot Basah $(\mathrm{g})$ & Bobot Berangkasan Kering $(\mathrm{g})$ \\
\hline $0 \mathrm{mg} \mathrm{kg}^{-1}$ & $169,88 \mathrm{a}$ & $56,21 \mathrm{a}$ \\
$100 \mathrm{mg} \mathrm{kg}^{-1}$ & $162,04 \mathrm{a}$ & $56,10 \mathrm{a}$ \\
$200 \mathrm{mg} \mathrm{kg}^{-1}$ & $179,49 \mathrm{a}$ & $61,93 \mathrm{a}$ \\
$300 \mathrm{mg} \mathrm{kg}^{-1}$ & $152,43 \mathrm{a}$ & $54,60 \mathrm{a}$ \\
$400 \mathrm{mg} \mathrm{kg}^{-1}$ & $145,59 \mathrm{a}$ & $47,43 \mathrm{a}$ \\
\hline BNJ 5\% & 87,68 & 35,05 \\
\hline
\end{tabular}

Keterangan: Angka yang diikuti dengan huruf yang sama tidak berbeda nyata menurut uji BNJ $\alpha=5 \%$.

Tabel 5. Pengaruh pemberian boron terhadap bobot basah tanaman dan bobot berangkasan kering tanaman padi (Data detransformasi antilog).

\begin{tabular}{lcc}
\hline Perlakuan & Bobot Ba sah $(\mathrm{g})$ & Bobot Berangka san Kering $(\mathrm{g})$ \\
\hline $0 \mathrm{mg} \mathrm{l}^{-1}$ & $179,35 \mathrm{a}$ & $59,61 \mathrm{a}$ \\
$5 \mathrm{mg} \mathrm{l}^{-1}$ & $140,54 \mathrm{a}$ & $48,44 \mathrm{a}$ \\
$10 \mathrm{mg} \mathrm{l}^{-1}$ & $166,92 \mathrm{a}$ & $57,79 \mathrm{a}$ \\
\hline BNJ 5\% & 87,68 & 35,05 \\
\hline
\end{tabular}

Keterangan: Angka yang diikuti dengan huruf yang sama tidak berbeda nyata menurut uji BNJ $\alpha=5 \%$.

Tabel 6. Pengaruh interaksi silika dan boron terhadap jumlah malai tanaman padi (Data detransformasi antilog).

\begin{tabular}{cccc}
\hline \multirow{2}{*}{ Perlakuan } & \multicolumn{3}{c}{ Boron } \\
\cline { 2 - 4 } & $0 \mathrm{mg} \mathrm{l}^{-1}$ & $5 \mathrm{mg} \mathrm{l}^{-1}$ & $10 \mathrm{mg} \mathrm{l}^{-1}$ \\
\hline Silika & & Jumlah malai tanaman \\
\hline $0 \mathrm{mg} \mathrm{kg}^{-1}$ & $15,14 \mathrm{~A} \mathrm{(a)}$ & $11,75 \mathrm{~A} \mathrm{(a)}$ & $12,16 \mathrm{~A} \mathrm{(a)}$ \\
$100 \mathrm{~m} \mathrm{~kg}^{-1}$ & $13,88 \mathrm{~A} \mathrm{(a)}$ & $10,59 \mathrm{~A} \mathrm{(a)}$ & $9,83 \mathrm{~A} \mathrm{(a)}$ \\
$200 \mathrm{mg} \mathrm{kg}^{-1}$ & $13,41 \mathrm{~A} \mathrm{(a)}$ & $12,45 \mathrm{~A} \mathrm{(a)}$ & $13,72 \mathrm{~A} \mathrm{(a)}$ \\
$300 \mathrm{mg} \mathrm{kg}^{-1}$ & $9,61 \mathrm{~A} \mathrm{(a)}$ & $15,49 \mathrm{~A} \mathrm{(a)}$ & $10,47 \mathrm{~A} \mathrm{(a)}$ \\
$400 \mathrm{mg} \mathrm{kg}^{-1}$ & $11,61 \mathrm{~A} \mathrm{(a)}$ & $6,49 \mathrm{~B} \mathrm{(b)}$ & $17,08 \mathrm{~A} \mathrm{(a)}$ \\
\hline BNJ 5\% & & 5,06 & \\
\hline
\end{tabular}

Keterangan : Angka pada tiap kolom yang diikuti dengan huruf yang sama (besar = horizontal, kecil = vertikal) tidak berbeda nyata menurut uji BNJ pada $\alpha=5 \%$.

penelitian El-feky et al. (2012) yang melaporkan bahwa penambahan boron dapat meningkatkan bobot segar dan bobot kering tanaman padi.

Terdapat interaksi silika dan boron terhadap jumlah gabah isi. Jumlah gabah isi mencapai optimum dan memiliki jumlah gabah isi terbanyak pada perlakuan yang diberi silika $400 \mathrm{mg} \mathrm{kg}^{-1}$ dan boron $10 \mathrm{mg} \mathrm{l}^{-1}$ yaitu 1748,64 butir rumpun ${ }^{-1}$ (Tabel 7). Bobot gabah isi mencapai optimum dan memiliki jumlah gabah isi terbanyak pada perlakuan yang diberi silika $400 \mathrm{mg} \mathrm{kg}^{-1}$ dan boron 10 $\mathrm{mg} \mathrm{l}^{-1}$ yaitu 35,01 $\mathrm{g}$ (Tabel 10). Dalam masing-masing penelitiannya Hyder et al. (2012) dan Kim et al. (2012);
Sarki et al. (2013) melaporkan bahwa boron maupun silika dapat meningkatkan jumlah gabah isi dan bobot gabah isi.

Persentase gabah isi tertinggi terdapat pada perlakuan yang diberi silika $200 \mathrm{mg} \mathrm{kg}^{-1}$ dan boron $5 \mathrm{mg}$ $1^{-1}$ yaitu $81,07 \%$. Persentase gabah isi terendah terdapat pada perlakuan tanpa diberi silika dan boron yaitu 40,33\% (Tabel 8). Hasil penelitian yang sama juga dilaporkan oleh Yasari et al. (2012) yang menyatakan dalam bahwa silika dapat meningkatkan persentase bulir isi. 
Tabel 7. Pengaruh pemberian silika dan boron terhadap jumlah gabah isi tanaman padi (Data detransformasi antilog).

\begin{tabular}{|c|c|c|c|}
\hline \multirow{2}{*}{ Perlakuan } & \multicolumn{3}{|c|}{ Boron } \\
\hline & $0 \mathrm{mg} \mathrm{l}^{-1}$ & $5 \mathrm{mg} \mathrm{l}^{-1}$ & $10 \mathrm{mg} \mathrm{l}^{-1}$ \\
\hline Silika & \multicolumn{3}{|c|}{ Jumlah gabah isi (butir) } \\
\hline $0 \mathrm{mg} \mathrm{kg}^{-1}$ & 792,96 A (a) & $1325,87 \mathrm{~A}(\mathrm{a})$ & $1062,31 \mathrm{~A} \mathrm{(a)}$ \\
\hline $100 \mathrm{mg} \mathrm{kg}^{-1}$ & $1555,07 \mathrm{~A}(\mathrm{a})$ & $1011,58 \mathrm{~A}(\mathrm{a})$ & $933,25 \mathrm{~A}(\mathrm{a})$ \\
\hline $200 \mathrm{mg} \mathrm{kg}^{-1}$ & $1603,25 \mathrm{~A}(\mathrm{a})$ & $1310,69 \mathrm{~A}(\mathrm{a})$ & $1462,18 \mathrm{~A}(\mathrm{a})$ \\
\hline $300 \mathrm{mg} \mathrm{kg}^{-1}$ & $1029,20 \mathrm{~A}(\mathrm{a})$ & 1640,59 A (a) & $1188,50 \mathrm{~A}(\mathrm{a})$ \\
\hline $400 \mathrm{mg} \mathrm{kg}^{-1}$ & $926,30 \mathrm{~A}(\mathrm{a})$ & $454,46 \mathrm{~B}(\mathrm{~b})$ & 1748,64 A (a) \\
\hline
\end{tabular}

Keterangan : Angka pada tiap kolom yang diikuti dengan huruf yang sama (besar = horizontal, kecil = vertikal) tidak berbeda nyata menurut uji BNJ pada $\alpha=5 \%$.

Tabel 8. Pengaruh interaksi silika dan boron terhadap persentase gabah isi tanaman padi (Data detransformasi antilog).

\begin{tabular}{cccc}
\hline \multirow{2}{*}{ Perlakuan } & \multicolumn{3}{c}{ Boron } \\
\cline { 2 - 4 } & $0 \mathrm{mg} \mathrm{l}^{-1}$ & $5 \mathrm{mg} \mathrm{l}^{-1}$ & $10 \mathrm{mg} \mathrm{l}^{-1}$ \\
\hline Silika & Gabah isi (\%) \\
\hline $0 \mathrm{mg} \mathrm{kg}^{-1}$ & $40,33 \mathrm{~B} \mathrm{(ab)}$ & $67,88 \mathrm{~A} \mathrm{(a)}$ & $60,04 \mathrm{~A} \mathrm{(a)}$ \\
$100 \mathrm{mg} \mathrm{kg}^{-1}$ & $68,28 \mathrm{~A} \mathrm{(a)}$ & $60,77 \mathrm{~A} \mathrm{(a)}$ & $79,07 \mathrm{~A} \mathrm{(a)}$ \\
$200 \mathrm{mg} \mathrm{kg}^{-1}$ & $72,13 \mathrm{~A} \mathrm{(a)}$ & $81,07 \mathrm{~A} \mathrm{(a)}$ & $65,53 \mathrm{~A} \mathrm{(a)}$ \\
$300 \mathrm{mg} \mathrm{kg}^{-1}$ & $70,36 \mathrm{~A} \mathrm{(a)}$ & $63,08 \mathrm{~A} \mathrm{(a)}$ & $75,55 \mathrm{~A} \mathrm{(a)}$ \\
$400 \mathrm{mg} \mathrm{kg}^{-1}$ & $63,97 \mathrm{~A}(\mathrm{a})$ & $71,79 \mathrm{~A} \mathrm{(a)}$ & \\
\hline BNJ 5\% & & 23,09 & $\mathrm{~A}(\mathrm{a})$ \\
\hline
\end{tabular}

Keterangan : Angka pada tiap kolom yang diikuti dengan huruf yang sama (besar = horizontal, kecil = vertikal) tidak berbeda nyata menurut uji BNJ pada $\alpha=5 \%$.

Tabel 9. Pengaruh pemberian silika dan boron terhadap gabah hampa tanaman padi (Data detransformasi antilog).

\begin{tabular}{|c|c|c|c|}
\hline \multirow{2}{*}{ Perlakuan } & \multicolumn{3}{|c|}{ Boron } \\
\hline & $0 \mathrm{mg} \mathrm{l}^{-1}$ & $5 \mathrm{mg} \mathrm{l}^{-1}$ & $10 \mathrm{mg} \mathrm{l}^{-1}$ \\
\hline Silika & \multicolumn{3}{|c|}{ Gabah hampa (but ir) } \\
\hline $0 \mathrm{mg} \mathrm{kg}^{-1}$ & $1184,75 \mathrm{~A}(\mathrm{a})$ & $625,52 \mathrm{~A}(\mathrm{~b})$ & 691,43 A (b) \\
\hline $100 \mathrm{mg} \mathrm{kg}^{-1}$ & 716,56 B (a) & $638,79 \mathrm{~A}(\mathrm{a})$ & $210,83 \mathrm{~B}(\mathrm{~b})$ \\
\hline $200 \mathrm{mg} \mathrm{kg}^{-1}$ & 606,04 B (a) & 299,04 B (b) & $760,11 \mathrm{~A}(\mathrm{a})$ \\
\hline $300 \mathrm{mg} \mathrm{kg}^{-1}$ & $424,86 \mathrm{~B}(\mathrm{~b})$ & $957,12 \mathrm{~A}(\mathrm{a})$ & $349,74 \mathrm{~A}(\mathrm{~b})$ \\
\hline $400 \mathrm{mg} \mathrm{kg}^{-1}$ & 516,33 B (a) & $159,82 \mathrm{C}(\mathrm{b})$ & 506,99 A (a) \\
\hline
\end{tabular}

Keterangan : Angka pada tiap kolom yang diikuti dengan huruf yang sama (besar = horizontal, kecil = vertikal) tidak berbeda nyata menurut uji BNJ pada $\alpha=5 \%$. 
Tabel 10. Pengaruh pemberian silika dan boron terhadap bobot gabah isi anaman padi (Data detransformasi antilog).

\begin{tabular}{cccc}
\hline \multirow{2}{*}{ Perlakuan } & \multicolumn{3}{c}{ Boron } \\
\cline { 2 - 4 } & $0 \mathrm{mg} \mathrm{l}^{-1}$ & $5 \mathrm{mg} \mathrm{l}^{-1}$ & $10 \mathrm{mg} \mathrm{l}^{-1}$ \\
\hline Silika & & Bobot gabah isi (g) \\
\hline $0 \mathrm{mg} \mathrm{kg}^{-1}$ & $20,07 \mathrm{~A} \mathrm{(a)}$ & $26,61 \mathrm{~A} \mathrm{(a)}$ & $24,06 \mathrm{~A} \mathrm{(a)}$ \\
$100 \mathrm{mg} \mathrm{kg}^{-1}$ & $31,08 \mathrm{~A} \mathrm{(a)}$ & $25,41 \mathrm{~A} \mathrm{(a)}$ & $21,50 \mathrm{~A} \mathrm{(a)}$ \\
$200 \mathrm{mg} \mathrm{kg}^{-1}$ & $34,67 \mathrm{~A} \mathrm{(a)}$ & $29,34 \mathrm{~A}(\mathrm{a})$ & $29,17 \mathrm{~A} \mathrm{(a)}$ \\
$300 \mathrm{mg} \mathrm{kg}^{-1}$ & $22,39 \mathrm{~A} \mathrm{(a)}$ & $34,67 \mathrm{~A}(\mathrm{a})$ & $26,30 \mathrm{~A} \mathrm{(a)}$ \\
$400 \mathrm{mg} \mathrm{kg}^{-1}$ & $18,49 \mathrm{~A} \mathrm{(a)}$ & $9,07 \mathrm{~B}(\mathrm{~b})$ & \\
\hline BNJ 5\% & & 11,68 & $\mathrm{~A} \mathrm{(a)}$ \\
\hline
\end{tabular}

Keterangan : Angka pada tiap kolom yang diikuti dengan huruf yang sama (besar = horizontal, kecil = vertikal) tidak berbeda nyata menurut uji BNJ pada $\alpha=5 \%$.

Terdapat interaksi silika dan boron terhadap jumlah gabah hampa. Tabel 9 menunjukkan bahwa tanaman padi yang tidak diberi silika dan boron memiliki jumlah gabah hampa terbanyak yaitu 1184,75 butir rumpun ${ }^{-1}$, sedangkan jumlah gabah hampa terkecil terdapat pada tanaman yang diberi silika $400 \mathrm{mg} \mathrm{kg}^{-1}$ dan boron $5 \mathrm{mg}$ $1^{-1}$ yaitu 159,82 butir. Hasil penelitian yang sama juga dilaporkan oleh Malidareh et al. (2011) dan Sarki et al. (2013) bahwa silika maupun boron dapat meningkatkan gabah isi dan menurunkan gabah hampa.

\section{KESIMPULAN}

Berdasarkan hasil penelitian, maka dapat diambil kesimpulan sebagai berikut: (1) pemberian silika 200 $\mathrm{mg} \mathrm{kg}^{-1}$ secara tunggal dapat meningkatkan tinggi tanaman padi dibandingkan tanpa diberi silika, perlakuan silika $200 \mathrm{mg} \mathrm{kg}^{-1}$ menghasilkan tinggi tanaman lebih besar 1,37 cm dibandingkan tanpa perlakuan silika. Pemberian boron $5 \mathrm{mg} \mathrm{l}^{-1}$ menghasilkan jumlah gabah hampa terendah yaitu 159,82 butir rumpun $^{-1}$ sedangkan tanpa pemberian boron jumlah gabah hampa mencapai 1184,75 butir rumpun $^{-1}$, dan (2) pemberian silika $400 \mathrm{mg}$ $\mathrm{kg}^{-1}$ yang dikombinasikan dengan boron $10 \mathrm{mg} \mathrm{l}^{-1}$ dapat meningkatkan pertumbuhan dan produksi tanaman padi berdasarkan variabel jumlah anakan, jumlah malai, jumlah gabah isi, persentase gabah isi, jumlah gabah hampa, dan bobot gabah isi.

\section{DAFTAR PUSTAKA}

Ahmad A., M. Tahir, E. Ullah, M. Naeem, M. Ayub, H. Rehman, and M. Talha. 2012. Effect of Silicon and Boron Foliar Application on Yield and Quality of Rice. Pak. J. Life Soc. Sci. 10(2): 161-165.
Aziz T., M. A. Gill, and Rahmatullah. 2002. Silicon nutrition and crop production: A review. Pak. J. of Agri. Sci. 39(3): 181-187.

El-feky S. S., F. A. El-Shintinawy, E. M. Shaker, and H. A. S. El-Din. 2012. Effect of elevated boron concentrations on the growth and yield of barley (Hordeum vulgare L.) and alleviation of its toxicity using different plant growth modulators. Australian Jurnal of Crop Science. 6(12): 1687-1695.

Heckman J. R. 2000. Boron: Needs of Soils and Crops in New Jersey. www.rce.rutgers.edu. Diakses pada hari minggu tanggal 3 Maret 2013 pukul 20.12 WIB.

Hyder S. I., M. Arshadullah, A. Ali, and A. I. Mahmood. 2012. Effect of Boron Nutrition on Paddy Yield Under Salinsodic Soils. Pakistan J. Agric. Res. 25(4): 266.

International Rice Research Institute. 2007. Informasi Ringkas Teknologi Padi. www. Knowlegdebank.irri.org. Diakses pada hari minggu 5 Mei 2013 pukul 14.23 WIB.

Khan R., A. R. Gurmani, M. S. Khan, Jalalludin, and A. H. Gurmani. 2011. Residual, Direct and Cumulative Effect of Boron Application on Wheat and Rice Yield Under Rice-Wheat System. Sarhad J. Agric. 27(2): 219-223. 
Kim Y. H., A. L. Khan, Z. K. Shinwari, D. H. Kim, M. Waqas, M. Kamran and I. J. Lee. 2012. Silicon Treatment to Rice (Oryza sativa L. cv 'Gopumbyeo') Plants Durring Different Growth Periods and Its Effects on Growth and Grain Yield. Pak. J. Bot. 44(3): 891-897.

Ma, J. F. and Takahashi, E. 2002. Soil, Fertilizer and Plant Silicon Research in Japan. Elsevier Science B. V. Amsterdam. 17-39.

Makarim K., E. Suhartatik, dan A. Kartohardjono. 2007. Silikon: Hara Penting pada Sistem Produksi Padi. Balai Besar Penelitian Tanaman Padi. 2(2): 195-204.

Malidarreh A. G., A. Kashani, G. Nourmohammadi, H. R. Mobasser, and S. V. Alvi. 2011. Silicon application and nitrogen on yield and yield components in rice (Oryza sativa) in two irrigation systems. American-Eurasian Journal of Agriculture and Environmental Science. (10): 532-543.
Mauad M., C. A. C. Crusciol, H. G. Filho, J. C. Corrêa. 2003. Nitrogen and Silicon Fertilization Of Upland Rice. Sci. Agri. 60(4): 761-765.

Salam A. K. 2012. Ilmu Tanah Fundamental. Global Madani Press: Lampung. 239-272.

Sarki M. S., Y. M. Khanif, C. I. Fauziah, A. W. Samsuri, and B. Hafeez. 2013. Comparative Evaluation of Colemanite and Sodium Pentaborate as Boron Sources for Rice Grown in Flooded Calcareous Soil. Sustainable Agriculture Research. 2(2): 134-141.

Sommer M., D. Kaczorek, Y. Kuzyakov, and J. Breuer. 2006. Silicon Pools and Fluxes in Soils and Landscapes-A review. J. Plant Nutr. Soil Sci. (169): 310-329.

Yasari E., H. Yazdpoor, H. P. Kolhar, and H. R. Mobasser. 2012. Effects of Plant Density and the Application of Silica on Seed Yield and Yield Components of Rice (Oryza sativa L.). International Journal of Biology. 4(4): 4653. 